\title{
TEKSKRITIEK EN DIE SOLA SCRIPTURA
}

\section{DR. P. J. THEO KOEKEMOER}

Die dogmatikus moet noukeurig en op kritiese wyse na die getuienis van die Heilige Skrif aangaande die onderwerp van sy navorsing luister. Hy staan by die begin van sy dogmatiese ondersoek voor 'n dubbele probleem, naamlik:

(a) Die Gevaar van Ontsporing: Hieronder verstaan ons die gevaar wat alle dogmatiese arbeid bedreig, naamlik dat dit in plaas van die sola Scriptura te laat geld, sy norme sal ontleen uit een of ander verabsoluteerde geskape werklikheid, byvoorbeeld uit die natuur en/of uit die rede. Indien hy hierdie maatstawwe binne die dogmatiek sou laat geld, is dit duidelik dat ons die feit (en bygevolg die belydenis) van onder andere die wonderwerke sal moet skrap, aangesien sodanige verhale indruis teen rede en ervaring.

Dan wanneer die dogmatiek wetenskap wil wees in die algemene sin, vind ontsporing plaas. Aan wetenskap in die algemene sin van die woord, word die volgende eise gestel:1):

1) Sy resultate moet nie bots met die wet van die kontradiksie nie;

2) Die resultate moet getoets kan word, dit wil sê dit moet kontroleerbaar wees;

3) Die resultate moet agting hê vir die fisiese en biologiese onmoontlikhede;

4) Sy ondersoek moet geen vooroordele bevat nie. (Die "Voraussetzunglosigkeit" daarvan moet duidelik wees);

5) Alle onderdele moet opgedeel kan word in aksiomas en bewysvoerings.

Hieruit is dit duidelik dat die resultate van alle pogings om die teologie in die sin van die ander wetenskappe sinvol te maak, die oorgawe van die vrye en soewereine openbaring van God aan die algemene konsepsie van die wetenskappe sou beteken. 'n Blik in die geskiedenis van die Teologie sou laasgenoemde kan illustreer. Karl Barth het hierdie poging van die 18de en 19de eeue treffend beskryf as die tyd van die „Verwissenschaftlichung oder Philosophisierung" van die teologie $e^{2}$ ).

Dit is deur hierdie verkeerde toepassing van maatstawwe van die algemene wetenskappe (waarin die "ratio" die hoofrol speel) op die teologie, dat die agtiende eeu as eeu van die

1) Karl Barth, Kirchliche Dogmatık, I, 1 bls. 7. Uitg. Evang. Verlag., Zollikon-Zürich.

2) Karl Barth: Die Protestantische Theologie im 19 Jahrhundert. Evang. Verlag. Zollikon. Zurich. S. 80. 
„,religiöse Aufklärung” meegebring het die „triomferende” kritiek op die kerk, Bybel en dogma. Dit was die tyd van die „Umdeuting" en "Negierung" van die openbaringswaarhede op grond van die Filosofie en Natuurwetenskap, die reduksie van die leer van die Christendom tot 'n natuurlike of "vernuftige Religion":3). So het die eis gekom vir die daarstelling van 'n nuwe „wetenskaplike”, ",gereinigde" tipe van Christelike leer, in ooreenstemming met die wêreldbeeld, die matematies-natuurwetenskaplike denke, die antroposentriese, outonomistiese filosofie; so staan die ,deugde" van die "histories ware" teenoor die wondere van die Bybel. Die gees van die mens het gestaan in die „Abneigung gegen das Wunder"'). Dit beteken onder andere: Drie kan nie een, en een kan nie drie wees nie - die Triniteitsleer is dwaasheid; geen „plaasbekledende geregtigheid”, geen „twee-nature” nie, geen regverdigingsleer in Reformatoriese sin nie, geen „eenmaligheid" van die openbaring nie; die Woord van God in Christus en die Bybel is histories te sien saam met die Woord van God by ander wyses en ander „Heilige Skrifte”; die psigologiese verklaring van die „testimonium Spiritus Sancti interum”. Kortom: Die wondere van die Bybel staan in botsing met die natuurwette.

Hierteenoor wil ons stel: Die ander wetenskappe het nie alleen die pagreg op die naam "scientia" nie. Ook teologie is „scientia", maar dan in hierdie sin: Die kriterium van die teologiese wetenskap (ook van die gods-geskiedenis is die openbaring van God in die vleesgeworde, geskrewe en gepredikte Woord"). Hierdie weg moet die dogmatikus volg in al sy konsekwensies. Hy moet eers luister, dan spreek (bely). Die „credere” is die vooronderstelling van die ,intelligere" en is daarom nie slegs 'n „credere id" nie, maar 'n „credo in”.

Die teoloog se „sapientia” en „scientia” is dus 'n wetenskap en 'n wysheid in heel besondere sin: Die dogmatikus het die fisiese en biologiese onmoontlike nie as sy probleem nie. Hy staan nie hier voor die eis van die Kausaliteit of wet van Kontradiksie nie, omdat God in sy openbaring vry en soewerein is en nie deur genoemde eise gebind word nie. Wat byvoorbeeld in Maria verwek is, is geen gevolg van 'n sigbare gebeure tussen Josef en Maria nie, maar dit druis teen alle natuurwette in. Dit is 'n daad van God. Daarom is die maagdelike geboorte van Christus nie te kontroleer deur die algemene konsepsie van die natuurwetenskappe nie.

3) Karl Barth: Die Protestantische Theologie, par. 3, bls. 80 vgl. ook E. Brunner, Dagmatik I, bls. 74.

t) Karl Barth: Die Protestantische Theologie, bls. 80-92.

5) Karl Barth, K.D. I, 1, bls. 291-305. 
Wanneer die dogmatikus van ,teologie" praat as 'n „wetenskap" verklaar hy daarmee ${ }^{6}$ :

1) Soos alle ander wetenskappe is dit 'n menslike poging om kennis te verkry van 'n bepaalde objek van kønnis. (Erkenntnisgegenstand).

2) Soos alle ander wetenskappe volg dit 'n bepaalde weg om die kennis te bereik.

3) Soos alle ander wetenskappe moet die teologie kan rekenskap gee waarom hy hierdie of daardie bepaalde weg volg.

Die ,parthenogenesis" kan ook biologies, met die maatstawwe van die biologiese of mediese wetenskappe ondersoek word. Die teoloog hoef, om „wetenskaplik" te wees, nie gebruik te maak van laasgenoemde wetenskappe se maatstawwe nie. Hy kan daarvoor wel agting hê, maar staan, vanaf sy basis gesien, in geen verpligting om die metodes van die bioloog te volg nie. Sy maatstaf is die Woord van God en die enigste eis wat aan sy metode gestel word, is dat dit die getuienis van die Heilige Skrif nie sal verhinder nie.

Die tweede probleem waarvoor die dogmatikus staan, is: Hoe moet die resultate van voorafgaande Skrifondersoek dogmaties waardeer word?')

In die voorafgaande opmerkings oor „Die Gevaar van Ontsporing", het ons besondere klem gelê op die "sola Scriptura". Die vraag, ná voorafgaande Skrifondersoek is egter nou: Indien ons sê „sola Scriptura”, watter „Scriptura” word bedoel? Om dit heel konkreet in ons verband te stel:

(a) Is (dogmaties gesien) in Matt. 1 vers 16 byvoorbeeld die Sir.-Sin. lesing die „Scripura” waarop die „sola Scriptura” sig betrek, of is een van die ander lesings wat Josef as Jesus se vleeslike vader uitsluit (en bygevolg die Parthenogenesis duidelik leer) „Scriptura”?

(b) Indien ons sou aanneem dat byvoorbeeld Harnack ${ }^{8}$ ) histories-krities bo alle redelike twyfel bewys het dat Luk. 1:34, 35 'n latere interpolasie is, mag ons dit dan nog as "Scriptura" beskou waarop die „sola Scriptura” sig rig? Met ander woorde kan 'n „latere interpolasie" nog vir die dogmatiek as kanoniek geld?

Dit is duidelik dat ons hier verskillende probleemkomplekse aanroer:

c) Karl Barth: Die Lehre vom Gottes. Erster Halbband. Fünfte Auflage. Evangelischer Verlag. Zollikon. Zürich, 1947. S. 7.

i) Vgl. vir die volgende prof. dr. B. J. Engelbrecht, Die Chiliasme, 'n lesing gehou voor die predikantevergadering, Pretoria, 1955.

8) Z.N.T.W., 1901, bls. 53 . 
(a) Die eerste is die vraagstuk van die draagkrag en gevolge van literêr-kritiese en histories-kritiese teksvasstelling vir die dogmatiek.

(b) Die tweede (wat hiermee saamhang) is die vraagstuk van wat vir die dogmatiek as kanoniek, as Skriftuurlik moet geld.

Hier kan ons die volgende aanmerkings maak:

(i) Dit is duidelik dat vir die kritiese teksvasstelling die aanneemlikste teks dié een is wat as gevolg van verskillende tekskritiese oorwegings, die mees-waarskynlike weergawe is van wat daar „oorspronklik" geskryf gestaan het. Dit is hieruit egter duidelik dat hierdie „oorspronklike teks" 'n wisselende grootheid is wat eerstens afhang van die huidige stand van ontdekkings en van die ontwikkeling van die tekskritiese wetenskap en tweedens van die skerpsinnigheid van die navorser(s). 'n Teks wat vandag „vasstaan" kan byvoorbeeld môre deur die ontdekking van nuwe materiaal, gesigspunte en so meer weer "wankelend" word en selfs deur 'n vroeër-onoorspronklike teks vervang word. Getuie hiervoor is byvoorbeeld die gedurige bywerking van die app. crit. van Nestle.

Die vraag is nou hoe kerk en dogmatiek tot 'n beslissing kan kom, gesien hierdie wisselende en altyd onvolledigblywende stand van die wetenskap van die teksvasstelling.

'n Verdere probleem in hierdie verband is wat die kriterium is van die ,oorspronklikheid" van 'n teks? Is „oorspronklik" alleen maar die "oorspronklike woorde" van Jesus en die histories-eksakte beskrywing van sy "lewe"? Of is „oorspronklik" alles wat in ,die Bybel" gestaan het met die kanonvasstelling aan die einde van die 4 de eeu?

Dit is duidelik dat ons met die begrip „oorspronklik" te doen het met 'n baie plastiese begrip, terwyl ons hier raak aan die probleem van kanon en kanonvasstelling.

(ii) Verder is dit 'n vraag of die eksegese tot taak het om alleen die sogenaamde "oorspronklike" teks te eksegetiseer, óf is dit die taak van die eksegese om met alle beskikbare wetenskaplike middels 'n suiwer uitleg te gee van alle beskikbare teksvariante afgesien van die huidige stand van literêre en histories-kritiese teksvasstelling?

(iii) Wat die dogmatiek betref, sirkel die hele vraag rondom die probleem van wat kanoniek is en wat nie? Hieromtrent die volgende opmerkings:

(a) Die eenvoudigste oplossing van hierdie probleem sou wees om aan te neem dat die kerk die kanon vasstel, ook in die geval van 'n enkele teks. Indien dit die geval sou wees, weet die eksegeet en dogmatikus op 'n gegewe oomblik presies watter 
teks of tekste eg is en bygevolg weet die dogmatikus of 'n leer wat hierop gebou is, Bybels is al dan nie, met ander woorde hy weet of die leer voldoen aan die stelreël: sola Scriptura.

Indien die kerk gesien word as onfeilbaar (Rome) dan beteken dit dat die kerk wel deur tekskritiek en eksegese geadviseer kan word vóór die teksvasstelling, maar wanneer die betrokke teks of tekste eers eenmaal vasgestel is en indien 'n kerklike leer eenmaal daarop gebou is, dan staan beide (teks en leer) vir altyd vas en alle kritiek (uit watter grond ookal) moet voor hierdie onfeilbare outoriteit swig.

Laat ons die volgende voorbeeld neem: Indien die onfeilbare kerk eenkeer (byvoorbeeld te Nicea) die maagdelike geboorte geleer het, dan het die kerk daarmee tegelykertyd ook die Bybeltekste in verband met die maagdelike geboorte as eg en kanoniek aanvaar, en dan kan geen teks- of histories-kritiese arbeid van die kant van die eksegese iets daaraan verander nie. Dit kan hoogstens apologetiese arbeid doen om die waarheid wat alreeds vasstaan, tekskrities te bewys.

Dit is duidelik dat ons hier beweeg binne die leer van die Rooms-Katolisisme. Hierteenoor het Zwingli egter alreeds in 1522/23 opgemerk: „Almal wat sê, die evangelie is niks sonder die goedkeuring van die kerk nie, dwaal en smaad God"'). Dieselfde het Calvyn ook in hierdie verband uitgespreek toe hy gesê het: „Die getuienis van die Heilige Gees is noodsaaklik om volle gesag aan die Heilige Skrif te verleen. Dit is goddeloos om voor te gee dat die geloofwaardigheid van die Skrif afhang van die oordeel van die kerk"$^{10}$ ). Veral hierdie laaste sitaat van Calvyn is instruktief, omdat dit aan ons laat sien dat die kerk nie buite die Skrif om enige outoriteit besit nie (veral nie outoriteit oor die Skrif nie, want hierin lê juis die kernvraag of die kerk vóór en buite-die-Skrif-om 'n outoriteit besit om oor die Skrif te oordeel).

(b) Maar hier is ook nog 'n ander weg wanneer ons aanneem dat die kerk die kanon vasstel, en dit is wanneer die kerk nie gesien word as onfeilbaar nie. Dan beweeg ons nader na die Reformasie toe, want dan is die gevolg dat die kerk weer-en-weer 'n kerklike beslissing aangaande die kanonisiteit van 'n teks (en bygevolg die Skriftuurlikheid van 'n leer as gevolg van daardie teks(te) ) kan hersien na aanleiding van die advies van die wetenskap van tekskritiek en eksegese. Hierdie openheid is ongetwyfeld 'n reformatoriese element in hierdie beskouing. Die swak

๑) Hudreich Zwinglis sămtliche Werke, Corpus Reformatorum, vol. LXXXIX, Bd. I, bls. 458 v.v.

10) Ioannes Calvinus, Institutio Religionis Christianae, Ed. 1559, I, VII. (Hoofstuk-opskrif). 
punt hiervan is egter daarin geleë dat die kerk nog altyd die subjek van kanonvasstelling bly, sodat die gevaar nog altyd dreig dat die kerk outoriteit vóór en buite-die-Skrif-om sou besit. Tereg het Calvyn daarop gewys dat nie die kerk die Skrif in aansyn roep nie, maar dat die Skrif die kerk in aansyn roep en daarom altyd prius van die kerk is en bly ${ }^{11}$ ).

(c) Ons is van mening dat ons die saak veeleer soos volg moet ste ${ }^{12}$ ): Dit is nie so dat die kerk die kanon vasstel buite die Skrifinhoud om nie. Dit is veeleer so dat die Skrif self, deur die Test. Spiritus Sancti sy eie kanonisiteit in en aan die kerk betuig en die kerk dit dan in gehoorsaamheid aan die Skrif aanvaar, in vaste vertroue op die belofte van die leiding van die Heilige Gees. Maar nou weet die kerk juis uit die Skrif, onder leiding van die Heilige Gees, van sy feilbaarheid. Daarom moet die kerk dan altyd weer sy beslissing aangaande die kanonisiteit van 'n teks of tekste (en die skriftuurlikheid van die leer o.g.v. daardie teks(te)) oophou vir korrektuur.

Indien ons hierdie beskouing toepas op die leer van die parthenogenesis, dan beteken dit (in teenstelling met Rome, waar ons dieselfde voorbeeld geneem het) die volgende: Die kerk het die maagdelike geboorte wel geleer as gevolg van die verstaan van die Skrif. Vandag nog herhaal die kerk weer-en-weer daardie beslissing, belydenis en leer, met ander woorde die kerk bely telkens weer die geloof saam met die kerk van alle eeue. Dit beteken dat die kerk vandag, net soos die kerk daar-en-toe, nog altyd daardie Skrifgedeeltes waarop die leer van die parthenogenesis gebou is, as eg, as Scriptura beskou, sodat in hierdie geval die „sola Scriptura” ondubbelsinnig geld. Die kerk beskou dit as "Scriptura" nie as gevolg van 'n eie outoriteit buite die Skrif om nie, maar as gevolg van die getuienis van die Skrifinhoud self deur die Test. Spiritus Sancti. Maar in teenstelling met Rome is daardie beslissing van vandag en gister egter nie vir altyd finaal nie. Dit bly altyd oop vir korreksie van die kant van die tekskritiek en eksegese. Maar dan ook goed verstaan: Dit is nie die wetenskap van die tekskritiek en eksegese wat die beslissing neem nie, maar die kerk. Tekskritiek en eksegese kan hoog. stens waarskuwend adviseer.

11) Vgl. Ioannes Calvinus, Institutio Ed. 1559, I, VII, 2 en A. van Selms, Lig uit Lig, J. H. de Bussy, Pretoria 1952, bls. 118-119.

12) Hierdie beskouing neem ons met instemming oor van prof. dr. B. J. Engelbrecht. 
Aan die begin het ons die vraag gestel: „Hoe moet ons die resultate van die voorafgaande Skrifondersoek dogmaties waardeer?" In die lig van bostaande uiteensetting kan ons nou soos volg antwoord: 'n Ondersoek in die Bybelse gedeeltes toon byvoorbeeld aan dat daar baie tekskritiese en histories-kritiese pro. bleme in verband met die tekste wat handel oor die maagdelike geboorte bestaan. Vanweë die aard van die wetenskap van die kritiese teksvasstelling, kan dit hoogstens op die waarskynlikste lesings heenwys en aantoon dat sommige lesings "oorspronklik” is en ander nie. Dit beteken egter nog nie dat die latere interpolasies en „onoorspronklike” lesings nie vir die kerk en dogmatiek „Scriptura” is nie. Dit beteken wel 'n waarskuwende advies vir kerk en dogmatiek. Hiermee sal dan ook in elke dogmatiese besinning weldeeglik rekening gehou moet word. 